\title{
DETERMINANTS WHICH AFFECT LIQUID ASSET RATIO OF CZECH AND SLOVAK COMMERCIAL BANKS
}

\author{
Pavla Vodová \\ Silesian University in Opava \\ School of Business Administration in Karviná \\ Department of Finance \\ Univerzitní nám. 1934/3, 73340 Karviná \\ E-mail:vodova@opf.slu.cz
}

\begin{abstract}
The aim of this paper is to find out determinants which affect liquid asset ratio of Czech and Slovak commercial banks. The data cover the period from 2001 to 2010. We consider four bank specific factors and nine macroeconomic factors. Results of panel data regression analysis showed that although Czech Republic and Slovak Republic have a lot in common, different factors determined banks' liquid assets in individual countries. The liquid asset ratio of Czech banks increases with increase of capital adequacy, with depreciation of Czech koruna and with worsening quality of credit portfolio. Liquidity of Slovak banks decreases with size of the bank, with higher capital adequacy, higher bank liquidity and during periods of financial crisis. Liquidity of Slovak banks is also positively related to economic cycle.
\end{abstract}

Keywords: liquid assets, panel data regression analysis, commercial banks, Czech Republic, Slovak Republic

JEL Classification: C23, G01, G21

\section{Introduction}

During global financial crisis, financial sector has gone through a dramatic re-appraisal of the liquidity risk. As a result of a continued drop in the market value of mortgage-backed securities from the subprime segment of the US market and the announcement of problems of some European banks, the interbank market came under extreme strain. This confidence crisis had the following consequences: (i) Amidst increased market nervousness, interbank interest rates sharply rose. (ii) Many segments of the structured credit and mortgage market ceased to trade at all, making it difficult to price outstanding positions. (iii) Investors sometimes failed to raise enough cash through asset sales. (iv) Interbank lending became scarce in a context of liquidity hoarding (Ewerhart and Valla, 2008). In response to the freezing up of the interbank market, the European Central Bank and U.S. Federal Reserve 
injected billions in overnight credit into the interbank market. However, some banks needed extra liquidity supports (Orlowski, 2008). Even with extensive support, a number of banks failed, were forced into mergers or required resolution (BIS, 2009).

It is evident that bank liquidity and liquidity risk is very up-to-date and important topic which should be of crucial importance of academicians and policymakers.

The aim of this paper is therefore to find out determinants which affect liquid asset ratio (which we use as an indicator of bank liquidity) of Czech and Slovak commercial banks.

The paper is structured as follows. Next section defines bank liquidity and characterizes methods of its measuring. Third section describes trends in liquid assets in Czech and Slovak banking sector. Following sections focus on the model and show results of regression analysis. Last section captures concluding remarks.

\section{Bank liquidity and its measuring}

Bank for International Settlements (BIS, 2008) defines liquidity as the ability of bank to fund increases in assets and meet obligations as they come due, without incurring unacceptable losses. Liquidity risk can arise on both sides of the balance sheet, if either the liquidity generated from selling or repo'ing assets or the liquidity available from various funding sources is insufficient to meet obligations as they fall due. In most cases a trigger event such as the crystallization of the market, credit or operational losses in the bank, damages of the bank's reputation or market-wide liquidity stress, meets already existing vulnerability in a bank's balance sheet and causes an adverse liquidity outcome (Matz and Neu, 2007). However, the most common source of bank vulnerability lies in liquidity mismatch between assets and liabilities - banks transform short-term deposits into long-term loans.

Liquidity risk includes two types of risk: funding liquidity risk and market liquidity risk. Funding liquidity risk is the risk that the bank will not be able to meet efficiently both expected and unexpected current and future cash flow and collateral needs without affecting either daily operations or the financial condition of the firm. Market liquidity risk is the risk that a bank cannot easily offset or eliminate a position at the market price. According to Crockett (2008), the dimension of market liquidity risk includes market depth (the ability to execute large transactions without influencing prices unduly); tightness (the gap between bid and offer prices); intermediacy (the speed with which 
transaction can be executed); and resilience (the speed with which underlying prices are restored after disturbance). Market liquidity risk and funding liquidity risk tend to reinforce each other: disruptions can easily spread from funding liquidity to market liquidity or vice versa (Baranyai, 2008).

The first symptom of a liquidity crisis in the banking sector generally takes the form of a liquidity deficit in the balance sheet of a bank (Valla et al., 2008). BIS (2008) recommends banks to identify alternative source of funding that strengthen its capacity to withstand a variety of severe yet plausible institutionspecific and market-wide liquidity shocks. Depending on the nature, severity and duration of the liquidity shock, potential sources of funding include the following:

- deposit growth;

- the lengthening of maturities of liabilities;

- new issues of short- and long-term debt instruments;

- intra-group fund transfers, new capital issues, the sale of subsidiaries or lines of business;

- $\quad$ asset securitization;

- the sale of highly liquid assets;

- drawing-down committed facilities;

- $\quad$ and borrowing from the central bank's marginal lending facilities.

However, not all of these options may be available in all circumstances and some may be available only with a substantial time delay. Bank management should regularly review and test its fund-raising options to evaluate their effectiveness at providing liquidity.

Aspachs et al. (2005) divide these possibilities into three main mechanisms that banks can use to insure against liquidity crises:

- Banks hold buffer of liquid assets on the asset side of the balance sheet. A large enough buffer of assets such as cash, balances with central banks and other banks, debt securities issued by governments and similar securities or reverse repo trades reduce the probability that liquidity demands threaten the viability of the bank.

- Second strategy is connected with the liability side of the balance sheet. Banks can rely on the interbank market where they borrow from other 
banks in case of liquidity demand. However, this strategy is strongly linked with market liquidity risk.

- The last strategy concerns the liability side of the balance sheet, as well. The central bank typically acts as a Lender of Last Resort to provide emergency liquidity assistance to particular illiquid institutions and to provide aggregate liquidity in case of a system-wide shortage.

Liquidity risk can be measured by two main methods: liquidity gap and liquidity ratios. The liquidity gap is the difference between assets and liabilities at both present and future dates. At any date, a positive gap between assets and liabilities is equivalent to a deficit (Bessis, 2009).

Liquidity ratios are various balance sheet ratios which should identify main liquidity trends. These ratios reflect the fact that bank should be sure that appropriate, low-cost funding is available in a short time. This might involve holding a portfolio of assets than can be easily sold (cash reserves, minimum required reserves or government securities), holding significant volumes of stable liabilities (especially deposits from retail depositors) or maintaining credit lines with other financial institutions. Various authors like Moore (2010), Praet and Herzberg (2008) or Rychtárik (2009) provide various liquidity ratios:

- Most common measure of liquidity risk is liquid asset ratio which is the share of liquid assets on total assets. This ratio should give us information about the general liquidity shock absorption capacity of a bank. As a general rule, the higher the ratio, the higher the capacity to absorb liquidity shock, given that market liquidity is the same for all banks in the sample. Nevertheless, high value of this ratio may be also interpreted as inefficiency. Since liquid assets yield lower income liquidity bears high opportunity costs for the bank. Therefore it is necessary to optimize the relation between liquidity and profitability. Moore (2010) notes that the liquid asset ratio has also its short-coming: it ignores the flow of funds from repayments, increases in liabilities and the demand for bank funds.

- The share of liquid assets on deposits and short term borrowing - this ratio is more focused on the bank's sensitivity to selected types of funding (deposits of households, enterprises, banks and other financial institutions and funds from debt securities issued by the bank); it should therefore capture the bank's vulnerability related to these funding sources. The higher is the value of the ratio, the higher is the capacity to absorb liquidity shock. 
- The share of liquid assets on deposits - this ratio is very similar to the previous one; however, it includes only deposits to households and enterprises. It measures the liquidity of a bank assuming that the bank cannot borrow from other banks in case of liquidity need. This is relatively strict measure of liquidity but it enables us to capture at least the part of the market liquidity risk. The bank is able to meet its obligations in terms of funding (the volume of liquid assets is high enough to cover volatile funding) if the value of this ratio is $100 \%$ or more. Lower value indicates a bank's increased sensitivity related to deposit withdrawals.

- The share of loans on total assets - it indicates what percentage of the assets of the bank is tied up in illiquid loans; therefore the higher this ratio the less liquid the bank is.

- The share of loans on deposits - it relates illiquid assets with liquid liabilities. Its interpretation is again: the higher this ratio the less liquid the bank is. Lower values of this ratio means that loans provide by the bank are financed by clients' deposits.

- The interbank ratio is computed as ratio of due from banks over due to banks. This ratio measures the position of a bank in the interbank market. If this ratio is greater than $100 \%$, then it indicates that the bank is net lender (and thus probably more liquid).

These liquidity ratios are still in common. It is possible to calculate them only on the basis of publicly available data from banks' balance sheets and it is easy to interpret their values. Their disadvantage is the fact that they do not always capture all, or any of liquidity risk.

\section{Trends in liquid asset ratio in Czech and Slovak banking sector}

First we will focus on development of liquid asset ratio of Czech and Slovak banks. We have used unconsolidated balance sheet data over the period from 2001 to 2010. As it can be seen from Table 1, the panel is unbalanced as some of banks do not report over the whole period of time.

The sample includes significant parts of both banking sectors (not only by number of banks but mainly by their share on total banking assets). Nevertheless, the share of observed bank on total assets may appear to be quite low. Partly it is a consequence of role of branches of foreign banks; partly it is because we do not include data from building societies, mortgage banks and from specialized banks like Českomoravská záruční a rozvojová banka, Slovenská záručná a rozvojová 
banka, Česká exportní banka or Exim banka which focus on very special financial products and services.

Table 1 Total number of banks and observed banks

\begin{tabular}{lcccccccccc}
\hline & $\mathbf{0 1}$ & $\mathbf{0 2}$ & $\mathbf{0 3}$ & $\mathbf{0 4}$ & $\mathbf{0 5}$ & $\mathbf{0 6}$ & $\mathbf{0 7}$ & $\mathbf{0 8}$ & $\mathbf{0 9}$ & $\mathbf{1 0}$ \\
\hline Czech Republic & & & & & & & & & & \\
\hline Total number of banks & 21 & 22 & 20 & 20 & 18 & 18 & 17 & 16 & 16 & 17 \\
\hline No. of observed banks & 15 & 16 & 16 & 16 & 16 & 13 & 13 & 12 & 12 & 13 \\
\hline $\begin{array}{l}\text { Share of observed banks } \\
\text { on total assets (in \%) }\end{array}$ & 68 & 74 & 74 & 74 & 72 & 74 & 75 & 66 & 67 & 68 \\
\hline Slovakia & 16 & 15 & 15 & 15 & 15 & 14 & 13 & 14 & 13 & 12 \\
\hline Total number of banks & 12 & 12 & 12 & 13 & 14 & 12 & 12 & 12 & 10 & 10 \\
\hline No. of observed banks & 56 & 52 & 56 & 59 & 65 & 62 & 65 & 70 & 66 & 65 \\
\hline $\begin{array}{l}\text { Share of observed banks } \\
\text { on total assets (in \%) }\end{array}$ & & & & & & & & & & \\
\hline
\end{tabular}

Source: author's processing

For these banks, we calculated liquid asset ratio. We include cash, government bonds, short-term claims on other banks and securities from trading portfolio in liquid assets. Figure 1 shows the development of liquid asset ratio of Czech and Slovak banks. It is evident that liquidity of Czech banks has declined during last ten years. On the contrary, during the period 2001-2008, value of the ratio for Slovak banks fluctuated only slightly. About one-third of assets of Slovak banks were liquid assets.

In both countries, we can see negative impact of financial crisis on bank liquidity. However, the extent of the impact differs among countries. Czech banks were least liquid in 2009 but there has been some improvement in last year. The fall of liquidity of Slovak banks in 2009 has been followed by an even deeper decline in 2010. The volume of banks' liquid assets decreased mainly as a result of reduction of interbank transaction in the respective years. This could be a signal of market liquidity risk - the interbank market has frozen because individual banks have not trust to each other. 
Figure 1 Liquid asset ratio of Czech and Slovak banks

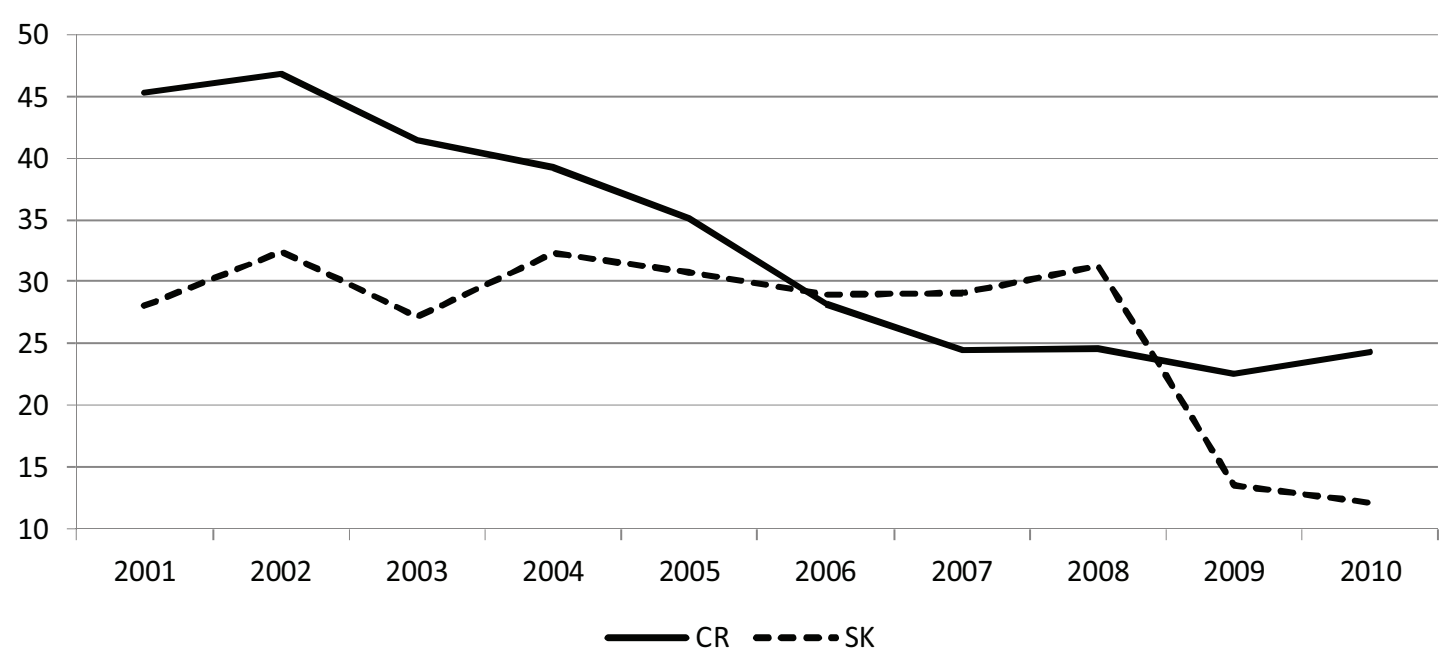

Source: author's calculation

\section{The model}

In order to identify determinants which affect liquid assets of Czech and Slovak commercial banks we use panel data regression analysis (Equation 1).

$$
L A R_{i t}=\alpha+\beta^{\prime} \cdot X_{i t}+\delta_{i}+\varepsilon_{i t}
$$

Where $L A R_{i t}$ is the liquid asset ratio for bank $i$ in time $t, X_{i t}$ is vector of explanatory variables for bank $i$ in time $t, \alpha$ is constant, $\beta^{\prime}$ is coefficient which represents the slope of variables, $\delta_{i}$ represents fixed effects in bank $i$, and $\varepsilon_{i t}$ means the error term.

It is evident that the most important task is to choose the appropriate explanatory variables. Although liquidity problems of some banks during global financial crisis re-emphasized the fact that liquidity is very important for functioning of financial markets and the banking sector, an important gap still exists in the empirical literature about liquidity and its measuring. Only few studies aim to identify determinants of liquidity.

Aspachs et al. (2005) study bank-specific and macroeconomic determinants of liquidity of 57 UK-resident banks, on data on a quarterly basis over the period from $1985 \mathrm{Q} 1$ to $2003 \mathrm{Q} 4$. They have found that the liquidity ratio is a function of:

- probability of obtaining the support from lender of last resort in case of a liquidity shortage (which lower the incentive to hold liquid assets); 
- short term interest rate which captures the monetary policy effect (the negative regression coefficient signals that when policy rates are high banks respond by holding a smaller amount of liquid assets);

- growth rate of gross domestic product (banks hold smaller amount of liquidity in periods of stronger economic growth);

- $\quad$ and interest margin as a measure of opportunity costs of holding liquid assets which has a negative impact on liquidity holdings.

For foreign owned banks, support from lender of last resort does not appear to affect their holding of liquid assets. When it comes to short term interest rate and growth rate of gross domestic product, these variables are statistically significant, too, but their effect on bank liquidity is smaller. Interest margin affects liquidity of foreign owned banks positively. Bank profitability; loan growth where higher loan growth should signal increase in illiquid assets and size of the bank are not statistically significant.

Determinants of liquidity risk of 1107 banks from 36 emerging economies in period 1995-2000 are analyzed by Bunda and Desquilbet (2008). Their main aim was to explore how the liquidity of commercial banks is affected by the exchange rate regime of the country in which they operate. They have found that in extreme regimes at both ends of the line (i.e. pure floating at one end and currency board and dollarized economies at the other end) banks are more liquid than in intermediate regimes. However, they focus also on other determinants both on macroeconomic and bank-specific level. According to their results, bank liquidity is positively influenced by:

- capital adequacy (higher capital adequacy is concomitant with higher liquidity);

- lending interest rate which is consistent with the credit rationing phenomenon;

- and the share of public expenditures on gross domestic product which measures supply of relatively liquid assets.

On the contrary, impact of financial crisis (which is very often caused by poor bank liquidity) is negative. The results show that the introduction of prudential regulation increases confidence in the banking sector so that banks can collect more deposits, thus increasing liquid liabilities, while, at the same time but to a lesser extent, investing more in illiquid projects. 
The empirical analysis of the hypothesis that interest rates affect banks' risk taking and the decision to hold liquidity across European countries provides Lucchetta (2007). The analysis is based on data of 5066 European banks over the period from 1998 to 2004. The study came to conclusion that across European countries, the interbank interest rate positively affects the liquidity retained by banks and the decision of a bank to be a lender in the interbank market. The key variable which affects the decision to lend in the interbank market is the liquidity price which depends on the demand and supply of liquidity and on the risk-free interest rate. The increase of this price increases the liquidity supply and thereby the lending in the interbank market. As this new liquidity is invested by borrowers in risky loans, the rise in risk-free interest rate increases banks' risk-taking behaviour (which is measured by the share of loans on total assets and share of loan loss provisions on net interest revenues). The results also showed that bank size matters: the lender banks tend to be smaller than borrower ones. The relation between monetary policy interest rate and the decision of a bank to hold liquidity and to lend in the interbank market is negative.

The effects of the financial crisis on the liquidity of commercial banks in Latin America and Caribbean countries investigated Moore (2010). The results based on monthly observations over the period January 1970 to December 2004 show that liquidity tends to be inversely related to the business cycle in half of the countries studied; and to the volatility of the cash-to-deposit ratio as well (which indicates that commercial banks tend to expand liquidity when the volatility of cash demand by the public rises). The effect of money market interest rate as a measure of opportunity costs of holding liquidity is mixed: the coefficient is positive in some countries and negative in some other countries (mainly in countries with relatively high interest rates). The relation between financial crisis and bank liquidity is also mixed: in six out of the nine countries, banks were less liquid during the crisis. This concerns in particular countries where there was a lending boom before the crisis or where banks were subject to large deposit withdrawals during the crisis. In other three countries, banks were more liquid during the crisis. In most of these countries the banking crisis was accompanied by an exchange rate crisis that probably led banks to be more conservative in their liquidity policies. However, such bank behavior can deeper the crisis if companies cannot access credits to finance their operations.

Liquidity created by all 457 German state-owned savings banks and its determinants in period from 1997 to 2006 has been analyzed by Rauch et al. (2010). According to this study, bank liquidity is determined by macroeconomic factors; mainly by: 
- monetary policy interest rate which has highly significant negative influence on bank liquidity (i.e. tightening monetary policy reduces bank liquidity);

- $\quad$ and level of unemployment which is connected with demand for loans and can also act as a proxy for general health of the economy and the negative influence means - the negative influence which has been proved indicate that the healthier the economy is, i.e. the lower the unemployment rate, the more liquidity is created by banks.

They do not find any bank specific factors, such as bank profitability or size of the bank measured by total number of bank customers, to have any influence on liquidity creation. Also the savings quota which should indicate the deposit behavior of private clients is not statistically significant.

Entirely unique is the approach of Fielding and Shortland (2005). Except of common determinants, they investigate the impact of violent political incidents arising from conflict between radical Islamic group and the Egyptian state. Based on data for the period 1983-1996, they have found that bank liquidity:

- is pro-cyclical (the level of economic output is taken into account by logarithm of real gross domestic product);

- responds positively also to increases in the discount rate (although this response seems only to be temporary);

- is positively related to the degree of macroeconomic instability which is captured by the rate of depreciation of the black market exchange rate;

- and negatively related to economic reforms which lead to reduction of excess liquidity.

However, the most important factor which impact on bank liquidity is number of violent political incidents: banks hold excessive liquid reserves in periods of political instability.

Cornet et al. (2011) study how banks managed the liquidity shock that occurred during the financial crisis of 2007-2009 by adjusting their holdings of cash and other liquid assets and how these efforts affected credit availability. Their sample included quarterly data of all US commercial banks over the period 2006Q1 through 2009Q2. They estimated regression function separately for small and large banks with following explanatory variables:

- the share of illiquid assets (such as loans, leases, asset-backed securities, mortgage-backed securities) on total assets; 
- the share of core deposits (i.e. deposits under USD 100000 plus all transactions deposits) on total assets;

- $\quad$ bank capital adequacy;

- $\quad$ and the ratio of unused commitments to commitments plus assets.

They came to conclusion that during the crisis, liquidity risk exposure led to greater increases in liquid assets, mirrored by greater decreases in credit origination. In other words, banks with more illiquid asset portfolios increased their holdings of liquid assets and decreased lending. The results showed significant differences between small and large banks. Mainly small banks that relied more heavily on stable sources of financing, i.e. core deposits and capital, continued to lend relative to other banks. Moreover, large banks have higher share of illiquid assets on total assets than small banks and also hold a greater fraction of unused commitments. Large banks are more exposed to liquidity risk than small banks across four dimensions: more undrawn commitments, less capital, less reliance on core deposits and lower liquidity of balance sheet assets. Off-balance sheet liquidity risk materialized as borrowers drew on pre-existing commitments in large quantities.

The selection of variables was based on above cited relevant studies. We considered whether the use of the particular variable makes economical sense in the Czech Republic and Slovakia. For this reason, we excluded from the analysis variables such as political incidents. We also considered which other factors could influence the behavior of banks in the interbank market. The limiting factor then was the availability of some data. Table 2 shows a list of variables which we have used in regression analysis.

We consider four bank specific factors and nine macroeconomic factors. As it can be seen from Table 2, we expect that three factors could have positive impact on bank liquidity, the rest of factors are expected to have negative impact on bank liquidity. Macroeconomic data were provided by International Financial Statistics of International Monetary Fund (IMF). Data about average exchange rates were provided by Oanda Corporation. Bank specific data were obtained from unconsolidated balance sheet and profit and loss data of banks' annual reports. 
Table 2 Variables definition

\begin{tabular}{llc}
\hline Variable & Source & Est.eff. \\
\hline CAP: the share of equity on total assets of the bank & $\begin{array}{l}\text { annual } \\
\text { reports }\end{array}$ & + \\
\hline $\begin{array}{l}\text { NPL: the share of non-performing loans on total volume } \\
\text { of loans }\end{array}$ & $\begin{array}{l}\text { annual } \\
\text { reports }\end{array}$ & - \\
\hline ROE: the share of net profit on banks' equity & $\begin{array}{l}\text { annual } \\
\text { reports }\end{array}$ & - \\
\hline TOA: logarithm of total assets of the bank & $\begin{array}{l}\text { annual } \\
\text { reports }\end{array}$ & $+/-$ \\
\hline $\begin{array}{l}\text { FIC: dummy variable for financial crisis } \\
\text { (1 in 2009, } \text { in rest of the period) }\end{array}$ & own & - \\
\hline $\begin{array}{l}\text { GDP: growth rate of gross domestic product } \\
\text { (GDP volume \% change) }\end{array}$ & IMF & $+/-$ \\
\hline INF: inflation rate (CPI \% change) & IMF & + \\
\hline IRB: interest rate on interbank transactions & IMF & + \\
\hline IRL: interest rate on loans & IMF & - \\
\hline $\begin{array}{l}\text { IRM: difference between interest rate on loans } \\
\text { and interest rate on deposits }\end{array}$ & IMF & - \\
\hline MIR: monetary policy interest rate & IMF & - \\
\hline UNE: unemployment rate & IMF & - \\
\hline EUR: exchange rate CZK(SKK)/EUR (yearly average) & Oanda & $+/-$ \\
\hline
\end{tabular}

Source: author's processing

\section{Results}

We used an econometric package EViews 7. After tests of stationarity, normality and multicollinearity, we proceed with regression estimation. We estimated Equation 1 separately for each country. First we included all explanatory variables which might have an effect on the dependent variable. To reduce number of explanatory variables, we used information criteria (Akaike, Schwarz and Hannan-Quinn). The aim was to find a regression model with high value of adjusted coefficient of determination in which all the variables involved are statistically significant.

Table 3 shows the results of the best estimation for Czech banks. The explanatory power of this model is quite high. The positive influence of the share of capital on total assets is consistent with the assumption that bank with sufficient capital adequacy should be liquid, too. The positive coefficient of exchange rate CZK/EUR signals that the depreciation of Czech koruna leads to higher liquid asset ratio. 
A substantial part of liquid assets creates interbank transactions. Czech banking sector is a net lender in interbank market (CNB, 2010); it is therefore highly probable that at least some Czech banks lend also to foreign bank. The profitability of such transactions increases with domestic currency depreciation. Therefore, the depreciation of Czech koruna can stimulate banks to focus more on international interbank transaction and thus increase their level of liquid assets.

Table 3 Determinants of liquid asset ratio in the Czech Republic

\begin{tabular}{lcc}
\hline Variable & Coefficient & Standard deviation \\
\hline Constant & $-48.70093^{*}$ & 10.45872 \\
\hline CAP & $0.348195^{*}$ & 0.102729 \\
\hline EUR & $2.577218^{*}$ & 0.359676 \\
\hline $\mathrm{NPL}$ & $0.463845^{* *}$ & 0.178999 \\
\hline Adjusted $\mathrm{R}^{2}$ & 0.738822 \\
\hline Durbin-Watson stat. & \multicolumn{2}{c}{1.753026} \\
\hline Total observation & \multicolumn{2}{c}{141} \\
\hline
\end{tabular}

Note: The starred coefficient estimates are significant at the $1 \%(*), 5 \%(* *)$ or $10 \%(* * *)$ level.

Although we estimated negative influence of non-performing loans, results of the analysis show the opposite effect. This could be a sign of prudent policy of banks: they offset the higher credit risk with cautious liquidity risk management.

Determinants of liquid assets of Slovak banks can be found in Table 4. The liquid asset ratio is determined by size of the bank, bank capital adequacy, profitability, growth rate of gross domestic product in previous year and by realization of financial crisis. The explanatory power of the model is slightly lower.

Table 4 Determinants of liquid asset ratio in the Slovak Republic

\begin{tabular}{lcc}
\hline Variable & Coefficient & Standard deviation \\
\hline Constant & $204.0059^{*}$ & 48.05892 \\
\hline TOA & $-11.76977^{*}$ & 3.147000 \\
\hline CAP & $-1.176136^{*}$ & 0.530005 \\
\hline ROE & $-0.104788^{* * *}$ & 0.054010 \\
\hline GDP $(-1)$ & $1.127757^{*}$ & 0.239350 \\
\hline FIC & $-12.20791^{*}$ & 3.276971 \\
\hline Adjusted R ${ }^{2}$ & 0.546390 \\
\hline Durbin-Watson stat. & \multicolumn{3}{c}{2.041361} \\
\hline Total observation & 105 \\
\hline
\end{tabular}

Source: author's calculation

Note: The starred coefficient estimates are significant at the $1 \%(*), 5 \%(* *)$ or $10 \%(* * *)$ level. 
According to our findings, small banks are more liquid than big banks. This finding fully corresponds to the well-known "too big to fail" hypothesis. If big banks are seeing themselves as "too big to fail", their motivation to hold liquid assets is limited. In case of a liquidity shortage, they rely on a liquidity assistance of Lender of Last Resort.

Although we expected that the bank with sufficient capital adequacy should be liquid, too, the results of the regression show the opposite influence of the share of capital on total assets. It seems that bank with lower capital adequacy pay more attention to liquidity risk management and hold a sufficient buffer of liquid assets.

The negative influence of bank profitability measured by return on equity is consistent with standard finance theory which emphasizes the negative correlation of liquidity and profitability.

Although most studies assumed the negative link between business cycle and bank liquidity, the results show that the approach of Moore (2010) can be applied on Slovak banking sector. Positive sign of the coefficient signals that cyclical downturn should lower banks' expected transactions demand for money and therefore lead to decreased liquidity. Moreover, during expansionary phases, companies (which have higher profits) and households (which have higher income) might prefer to rely more on internal sources of finance and reduce the relative proportion of external financing and might reduce their debt levels. In recessions, households and corporations may increase their demand for bank credit in order to smooth out the impact of lower income and profits. Growth rate of gross domestic product is statistically significant with one year lag which is consistent with the fact that companies and households need some time for accumulating profits and savings and therefore it takes some time for changes to be reflected in banks' liquidity.

The negative impact of financial crisis has been mentioned above. Financial crisis could be caused by poor bank liquidity. However, the effect may be the opposite: financial crisis lead to poor bank liquidity. Financial crisis affects banks in two different ways. First, the volatility of important macroeconomic variables influences unfavorably the business environment of banks. Second, the instability deteriorates the business environment of borrowers; it can worsen their ability to repay the loans which can lead to a decline in bank liquidity. The impact of financial crisis is also consistent with impact of previous variable (growth rate of gross domestic product). 


\section{Conclusion}

The aim of this paper was to find out determinants which affect liquid assets of Czech and Slovak commercial banks. Initially, we have focused on development of liquid asset ratio. Liquidity of Czech banks has declined during last ten years. On the contrary, liquidity of Slovak banks fluctuated only slightly during the period 2001-2008. Bank liquidity has fallen due to the financial crisis in both countries. However, the extent of the impact differs: Czech banks were least liquid in 2009 but there has been some improvement in last year; the fall of liquidity of Slovak banks in 2009 has been followed by an even deeper decline in 2010.

Furthermore, we focus on determinants of liquid asset ratio. Results of panel data regression analysis showed that the liquid asset ratio is determined mostly by different factors in each country (only capital adequacy matters in both countries but with different impact).

The liquid asset ratio of Czech banks increases with increase of capital adequacy, with depreciation of Czech koruna (which stimulates banks to focus more on international transaction in interbank market) and surprisingly with worsening quality of credit portfolio (banks offset higher credit risk by more prudent liquidity risk management).

Liquidity of Slovak banks is determined by size of the bank (small banks are more liquid); bank capital adequacy (banks with lower capital adequacy hold higher buffer of liquid assets), bank profitability (which is negatively correlated with liquidity), growth rate of gross domestic product in previous year (which is positively related to bank liquidity) and by realization of financial crisis (where realization of financial crisis worsen bank liquidity).

\section{Acknowledgement}

This paper was prepared with financial support of Czech Science Foundation (Project GAČR P403/11/P243: Liquidity risk of commercial banks in the Visegrad countries).

\section{References}

Aspachs, O. et al. (2005). Liquidity, Banking Regulation and the Macroeconomy. Evidence on bank liquidity holdings from a panel of UK-residents banks. Retrieved from: http://www.bis.org/bcbs/events/rtf05AspachsNierTiesset.pdf

Baranyai, E. (2008). Liquidity Risk Management with special interest to the Hungarian banking sector. Saarbrücken: VDM Verlag Dr. Müller. 
Bessis, J. (2009). Risk Management in Banking. Chichester: John Wiley \& Sons. BIS (2008). Principles for Sound Liquidity Risk Management and Supervision. Basel: Bank for International Settlements.

BIS (2009). International framework for liquidity risk measurement, standards and monitoring. Basel: Bank for International Settlements.

Bunda, I. and Desqioůbet, J. B. (2008). The Bank Liquidity Smile Across Exchange Rate Regimes. International Economic Journal, 22(3), pp. 361-386.

Cornet, M. M. et al. (2011). Liquidity risk management and credit supply in the financial crisis. Journal of Financial Economics, 101(2), pp. 297-312.

Crockett, A. (2008). Market liquidity and financial stability. In Banque de France Financial Stability Review. Paris: Banque de France, pp. 13-17.

CNB (2010). Financial market supervision report. Prague: Czech National Bank.

Ewerhart, C. and Valla, N. (2008). Financial market liquidity and the lender of last resort. In Banque de France Financial Stability Review. Paris: Banque de France, pp. 133-148.

Fielding, D. and Shortland, A. (2005). Political Violence and Excess Liquidity in Egypt. Journal of Development Studies, 41(4), pp. 542-557.

Lucchetta, M. (2007). What Do Data Say About Monetary Policy, Bank Liquidity and Bank Risk Taking? Economic Notes by Banca Monte dei Paschi di Siena SpA, 36(2), pp. 189-203.

Matz, L. and Neu, P. (2007). Liquidity Risk Measurement and Management. A practitioner's guide to global best practices. Singapore: John Wiley \& Sons.

Moore, W. (2010). How do financial crises affect commercial bank liquidity? Evidence from Latin America and the Caribbean. MPRA Paper no. 2010-21473. Munich: Munich Personal RePEc Archive.

Orlowski, L. T. (2008). Stages of the 2007/2008 Global Financial Crisis: Is There a Wandering Asset-Price Bubble? Economic Discussion Paper no. 2008-43. Retrieved from: http://www.economics-ejournal.org/economics/discussionpapers/ 2008-43.

Praet, P. and Herzberg, V. (2008). Market liquidity and banking liquidity: linkages, vulnerabilities and the role of disclosure. In Banque de France Financial stability Review. Paris: Banque de France, pp. 95-109.

Rauch, C. et al. (2010). Determinants of Bank Liquidity Creation. Retrieved from: http://papers.ssrn.com/sol3/papers.cfm?abstract_id=1343595 
No. $1 / 2013$

Rychtárik, Š. (2009). Liquidity Scenario Analysis in the Luxembourg Banking Sector. BCDL Working Paper 2009-41. Luxembourg: Banque Centrale du Luxembourg.

Valla, N. et al. (2006). Bank liquidity and financial stability. In Banque de France Financial Stability Review. Paris: Banque de France, pp. 89-104. 